\title{
NUEVAS APORTACIONES ICONOGRÁFICAS Y SIMBÓLICAS EN LA SACRISTÍA DE LA IGLESIA DE LA MAGDALENA DE SANTAMERA (GUADALAJARA).
}

\section{NEW ICONOGRAPHIC AND SYMBOLIC CONTRIBUTIONS IN THE SACRISTY OF THE CHURCH OF LA MAGDALENA DE SANTAMERA (GUADALAJARA).}

\author{
Cristina Jiménez Balbuena \\ Escuela Internacional de Doctorado \\ Universidad Rey Juan Carlos
}

\section{RESUMEN}

El estudio aborda el análisis de unas pinturas recientemente descubiertas en la sacristía de la iglesia parroquial de Santamera, una aldea de la tierra de Atienza, marcada por su situación geográfica y por la multiculturalidad de su pasado histórico. El templo, distinguido por su advocación a la Magdalena, da muestras en sus orígenes del románico comarcal, pero también en su evolución de las formas renacentistas y del lenguaje dogmático del barroco. En ese contexto debemos situar unas pinturas excepcionales por la singularidad de su ubicación y por su temática, pudiéndose distinguir en ellas dos momentos asociados a la espiritualidad del obispado de Sigüenza en esa época. La más antigua, un Juicio Final, parece recordar a los clérigos su falta de ortodoxia y la necesidad de una renovación espiritual en el seno de la Iglesia. Las segundas, en una iconografía eucarística incorporan lo exótico, y también en una representación única, el paso de la embajada japonesa de 1614 por el valle del Salado en su viaje a Roma. Escenas que podemos interpretar como evidencia del triunfo del cristianismo contra la herejía en el lenguaje propagandístico de la Iglesia postridentina.

Palabras clave: Juicio Final, ortodoxia, renovación espiritual, catequesis, embajada japonesa.

\begin{abstract}
Santamera is a village in Atienza, marked by its location and its historical and multicultural past. This article analyses some recently discovered paintings in the sacristy of the local parish church. The church, with a Romanesque origin, is dedicated to the Magdalena, but in its evolution also shows Reinaissance and Baroque forms. There can be found some exceptional paintings in which we can distinguish two moments associated with the spirituality of the bishopric of Sigüenza at that time.The earliest, a Last Judgement, seems to remind the clerics their lack of ortodoxy and the need for spiritual renewal within the church. The second, in a Eucharistic iconography, adds the passage of three Japanese Embassy of 1614 through the Salado Valley on its journey to Rome. These scenes can be read as evidence of the triumph of Christianity over heresy in the propaganda language of the post-Tridentine Church.
\end{abstract}

Keywords: Last Judgement, orthodoxy, spiritual renewal, catechesi, Japanese Embassy. 


\section{INTRODUCCIÓN}

En la actualidad, Santamera es una pequeña aldea perteneciente al municipio de Riofrío del Llano en la provincia de Guadalajara. Como la mayor parte de los pueblos de la comarca presenta una configuración urbanística medieval con origen en las repoblaciones cristianas del siglo XIII, aunque un análisis más profundo haya permitido distinguir para esta ubicación dos núcleos diferenciados, Sancta Mayre y Santa Mera, testigos en el tiempo de la evolución histórica de su poblamiento y de la manifestación religiosa de sus gentes.

Para entender el simbolismo cultural y religioso que encierran algunas de las manifestaciones artísticas de las aldeas del valle del Salado es necesario retrotraerse en el tiempo y conocer las singularidades que marcaron el carácter fronterizo de esta comarca, punto de encuentro del Sistema Central con la Cordillera Ibérica. Esta ubicación determinó que la historia del valle del Salado ${ }^{1}$ fuera rica y compleja, mostrando a nivel local una simbiosis propia de las zonas limítrofes y del aprovechamiento de un peculiar ecosistema, los saladares (Gismera, 2016:27-36 y 55). En esta configuración del territorio no podemos olvidar la importancia de Atienza y Sigüenza, espacios que desde la Antigüedad marcaron el devenir histórico de las diferentes culturas y asentamientos de la comarca. Por ello, ha sido en la microhistoria de esas aldeas olvidadas, en el discurrir de la cotidianidad, donde la asociación de elementos en apariencia sin trascendencia permite explicar manifestaciones artísticas como las halladas en la sacristía de la Magdalena. Una obra inédita que, en un contexto religioso determinado por la directrices del obispado seguntino, sorprende al estudioso con particularismos que se escapan a la norma, enriqueciendo la visión del hecho religioso de una comarca marcada por la multiculturalidad.

\section{LA IGLESIA PARROQUIAL DE SANTA MARÍA MAGDALENA (SANTAMERA, GUADALAJARA).}

El templo de Santa María Magdalena respondió en su configuración a la fundación de una aldea de repoblación, a la sacralización del terrazgo y a la necesidad parroquial de una necrópolis, destacada en el tiempo por una singular estela antropomorfa, la Cruz de los Ángeles. Entre sus diferentes reformas, la iglesia actual todavía insinúa los restos de un primitivo templo parroquial románico que, en el análisis de su fábrica, evidencia la difusión comarcal de un modelo de edificio articulado en dos partes diferenciadas, cabecera cuadrangular y nave única, construidos en mampostería local y en una cantería roja característica del obispado seguntino.

La humildad inicial del edificio y su decrepitud debieron ser razones suficientes para que, ante la ausencia de unos elementos románicos llamativos, se reedificara con una cabecera gótica más al gusto del señorío al que perteneció desde la Baja Edad Media, así como de un obispado inmerso en la remodelación del crucero de la catedral seguntina según las nuevas tendencias artísticas. La reforma principal, considerada por sus coetáneos como "fábrica goptica"2, se centró en la elevación de la cabecera, permitiendo el trazado de un diseño de terceletes, de un arco presbiterial de mayor luz y de una armadura mudéjar de par y nudillo. Asociado a estas obras, el individualismo propio de la espiritualidad de la devotio moderna y el acceso de las élites al espacio funerario ad santos, hicieron posible la incorporación a la fábrica de dos capellanías de altar con su característico retablo mural en el testero, su advocación mariana y su inscripción como muestra de la religiosidad del donante. Todo ello, en una adscripción estilística cercana al Gótico isabelino o estilo Reyes Católicos, sin duda, interpretados en su encargo como un signo de modernidad (Ramos, 2004:18-19).

La importancia política y cultural de obispos como el cardenal Mendoza (1467-1495),

1 El cañón que forma el río Salado a su paso por la localidad fue ruta obligada desde la prehistoria, siendo también camino en las algaradas medievales de musulmanes y cristianos, justificando los primeros su defensa con un hisn que formó parte de la estrategia defensiva de la Marca Media. Con ello, sirva como referencia más conocida, el itinerario geográfico del Cantar del mío Cid donde se describe como Rodrigo Díaz de Vivar en compañía de Alvar Fañez de Minaya entró en Guadalajara por Robledo, Santamera y Huérmeces. Además, la ruta se mantuvo viva en el tiempo con el tránsito de la lana y como camino real de los apeos de la sal de Imón.

2 Archivo Histórico Diocesano de Sigüenza, Sigüenza (AHDS, Sigüenza). Archivo parroquial de Santamera, Libro de fábrica de 16011635. Caja $\mathrm{n}^{\circ} 1$. 
D. Bernandino de López de Carvajal (1495-1512) y D. Fadrique de Portugal (1512-1532) permitieron la creación de un círculo seguntino de artistas que centraron sus encargos, bien en la catedral, bien en las parroquias del obispado. En este sentido, el ornato de la iglesia de la Magdalena de Santamera permite observar la evolución de las directrices religiosas impuestas por el Obispado de Sigüenza, pudiéndose distinguir en su retablística dos espiritualidades asociadas. Un primer periodo, en línea con una dirección eclesial aperturista e integradora, representado por la incorporación de las formas renacentistas al retablo plateresco del altar mayor de la Magdalena (1550-1560), una obra diseñada para una minoría culta con alta sensibilidad estética, y una segunda etapa que muestra en los retablos colaterales la difusión de los dogmas de la Contrarreforma. Con ello, es de destacar que la Magdalena no fue representada en su misticismo más arrebatado, si no en la monumentalidad de un artista continuador de las formas del maestro Juan Soreda, creando un estilo propio que ha servido para diferenciar al Maestro de Santamera (Layna, 1944:9), (Marco, 1997:44,68), (Ramos, 2003: 35-59) y (Ramos, 2004: 292-293 y 300-307).

Fue en ese tránsito hacia la modernidad cuando se debió realizar la sacristía del Magdalena (Carrero, 2005:49-75) ${ }^{3}$. Un espacio necesario en la obligación de dotar a los altares de una zona específica para el depósito de los ornamentos destinados a los oficios diarios, aunque en su decoración, la sacristía de la Magdalena contenga un simbolismo solojustificable en el carácter judaizante de los clérigos del obispado de Sigüenza, en el humanismo que irradia la Magdalena y en la falta de ortodoxia de una religiosidad marcada por la multiculturalidad de la comarca (Cantera y Carrete, 1973/b:260-323) y (Carrete y Moreno, 1995:283-292).

\section{APORTACIONES ICONOGRÁFICAS DE LA SACRISTÍA DE SANTA MAGDALENA.}

La sacristía de la Magdalena no destacaría por ninguno de sus elementos sino fuera por la sorprendente decoración de sus muros. Recientemente, los restos de unos fragmentos pictóricos descubiertos bajo la cal han permitido iniciar el estudio preliminar de un conjunto que debió decorar la estancia hasta el siglo XIX ${ }^{4}$, fecha estimada en que se encaló la sacristía. Pinturas que por su ubicación y temática muestran la dirección espiritual del obispado seguntino, en cuanto fueron obras dirigidas al clero ${ }^{5}$ al ser el espacio donde los sacerdotes se preparaban antes de iniciar la liturgia de la misa, y como tal, refieren una alusión al sacerdocio, a la Eucaristía y a los valores de la evangelización en un lugar de recogimiento.

Es difícil hacer una comparación con las sacristías de las iglesias parroquiales de la comarca porque la mayoría están encaladas y han perdido su compostura original. Sin embargo, sacristías como la del monasterio de Guadalupe, El Escorial o la seguntina de las Cabezas parecen mostrar cual fue el sentido inicial de un espacio concebido con una función pastoral y pedagógica, lugar donde los clérigos debían recordar los principios necesarios para alcanzar la perfección en el ejercicio eclesiástico y prepararse como los administradores de los misterios del Señor en servicio de su pueblo. Es en esa ansiada perfección cuando los clérigos deberán cumplir fielmente las tareas del ministerio pastoral, alimentando su espíritu

3 La cronología inicial para este tipo de sacristías en la comarca es del siglo XV, empleándose por lo general el modelo de estancia de planta rectangular, dotado de cajoneras y armarios donde recoger los objetos litúrgicos, un "sacrario" y, en ocasiones, hasta una fuente para las abluciones litúrgicas. En el desarrollo de este diseño es de destacar la magnífica sacristía plateresca de las Cabezas de la catedral de Sigüenza. Este esquema se repetirá hasta el siglo XVIII. La construcción de la sacristía de la Magdalena siguió las pautas constructivas del gótico tardío, edificándose como un anexo a la cabecera, probablemente, en algún momento del final del siglo XV o principios del XVI. El cuerpo constructivo es de obra de mampostería y planta rectangular con tejado a tres aguas y alfarje sencillo.

4 El descubrimiento de las pinturas fue casual y tuvo lugar durante el estudio de la fábrica de la iglesia. Por conservación no se ha procedido a su total levantamiento. De ahí, la parcialidad de nuestra aproximación, debiendo entenderse como un estudio previo a los trabajos de restauración.

5 Una de las reformas de Trento que más afectó a los clérigos locales fue la obligación de residir en la localidad donde estuvieran ubicadas las parroquias. Santamera no contó con cura propio, ocupándose de la parroquia, bien un clérigo de Huérmeces, bien como curato el sacerdote de Imón o de la Olmeda. En general, el absentismo clerical fue un problema muy extendido en la época bajomedieval, afectando principalmente a las pequeñas parroquias. Esta situación quedó reflejada en varios documentos que muestran el malestar de la comunidad, entre ellos, el fechado en 1571-1585 “ Sobre residencia del párroco en el lugar”. AHDS, Sigüenza. Archivo parroquial de Santamera,1571-1585. Caja n ${ }^{\circ}$ 2, 13 Ab6, y un segundo, donde el concejo reitera las ausencias "El Concejo con Baltasar Sanz sobre que resida dicho curato o ponga teniente".1648-02. AHDS, Sigüenza. Archivo parroquial de Santamera. Caja $\mathrm{n}^{\circ} 2,07 \mathrm{Ad} 7$. 
con la Sagrada Escritura, la Eucaristía y la penitencia, todo ello, observando una contingencia perfecta, pues en el celibato los ministros sagrados se pueden dedicar con mayor libertad a Dios y a los hombres.

En su presentación, la decoración de la sacristía presenta dos propuestas temáticas diferenciadas: la principal, por su situación en el testero, se correspondería con la representación del Juicio Final, y las colaterales, con el paso de una comitiva dispuesta en dos escenas dentro de una iconografía común, con personajes bien en actitud andante, bien oferentes, en una presentación que invita al espectador a marchar hacia el este, probable destino final de su viaje. Finalmente, una tercera escena, en relación con la propuesta anterior, podría ser interpretada como el recibimiento de un séquito en una gran ciudad o también como el principio de un largo peregrinar en la consecución de sus objetivos.

La decoración que enmarca las pinturas no es fácil de adscribir a un estilo concreto, dado lo parcial de su descubrimiento y lo genérico del motivo representado. Sobre zócalo, dos de las escenas aparecen encuadradas por una cenefa de lacería donde el cruce de las cintas genera un polígono con decoración cordada que se aproxima al símbolo franciscano, en lo que podría ser una alusión a los tres votos de la orden: pobreza, castidad y obediencia o bien a las cinco llagas de Cristo. También, aunque a penas descubierto, un friso corrido inscrito complementará los detalles y autoría de la obra. Además, en la escena principal, figura otra cartela a modo de filacteria sostenida por ángeles, quizás con la escritura volteada hacia atrás, es decir, para leer aparentemente en espejo 6 .

La técnica de estas pinturas deja ver un dibujo preparatorio realizado con un lápiz graso de color negro utilizado directamente sobre el muro enlucido que, en su desarrollo, permite observar las líneas de encuadre y una aparente policromía en algunos personajes y motivos iconográficos. El resultado final es de una obra una inconclusa. Sin embargo, una visión más detallada del sombreado de la segunda propuesta iconográfica, muestra como quizás esté acabado fue intencionado, pues las pinceladas usadas en seco o en húmedo forman trazos perpendiculares o inclinados que en alternancia con la línea y con las zonas de tinta permitieron al artista crear texturas, haciendo innecesaria la aplicación del color. Además, sorprende para la época, la falta de preocupación por la profundidad, por la dimensionalidad de las figuras, y en contraste, el empleo de los fuertes diseños gráficos de líneas marcadas que enfatizan su naturaleza plana y su monocromía. Igualmente, muestra un tratamiento exquisito de las representaciones de la flora y la fauna, con una visión intuitiva de lo natural, dentro de un diseño sencillo que economizó recursos para despojarse de lo ficticio en pro de lo espiritual (García, 1967:17-21)7. Este aspecto abocetado de las representaciones confiere al segundo conjunto una plasticidad próxima a la acuarela o a la estampación en tinta, siendo un aspecto a tener en cuenta en la interpretación de la obra (González, 2005:761 y 784).

Con ello, analizaremos al menos dos propuestas iconográficas sin aparente relación, un Juicio Final y tres escenas, posiblemente, de la representación de la embajada japonesa que visitó en 1614 la corte de los Austrias en su viaje a Roma, tema sin duda singular que podríamos relacionar por sus símbolos con la Eucaristía y el triunfo de la fe contra la herejía. Es difícil dar una fecha para el conjunto pictórico, pues si bien la iconografía de la primera obra sitúa la representación como un modelo anterior a 1563, su relación con el marco de las tres escenas de la comitiva japonesa aproxima las pinturas a los primeros años del siglo XVII. Indudablemente, esta posible datación afectaría a nuestra interpretación, pues el Juicio Final podría corresponder a la reproducción de un grabado más conservador o a una reutilización asimilada como parte de la nueva composición, aunque en su contra exista un paralelo de San Miguel con el mismo simbolismo y documentado como obra anterior a Trento en la iglesia cercana de El Atance.

6 Hay varias posibles explicaciones que justificarían este tipo de escritura en el periodo histórico propuesto. La primera, se correspondería con la concepción neoplatónica que confiere a este tipo de escritura un valor metafórico relacionado con el "speculum aenigmaticum", aunque también se pueda entender en la lectura de un pasaje de San Pablo sobre el conocimiento de la verdadera realidad cuando estemos en presencia de Dios.

7 El autor hace una reflexión sobre la visión del arte japonés realizada por el jesuita portugués, Juan Rodríguez Tsuzu, en el siglo XVII. 


\subsection{UN JUICIO FINAL ANTERIOR A TRENTO.}

El Juicio Final es un tema iconográfico muy repetido desde la Edad Media tanto en la decoración de los testeros absidiales, portadas, como con adaptaciones diversas en las capillas funerarias, grabados y lienzos posteriores, a pesar de lo cual, no se han encontrado referentes que permitan interpretar un Juicio Final en el contexto de una sacristía. En su valoración, Trento supuso la renovación del viejo tema simbólico", pues el modelo cambió a partir del "Decreto sobre el Purgatorio" , adquiriendo una estructura precisa sobre el que asentar las verdades dogmáticas (Borja, 2009:80-100) y (Castro, 2007:39-61). De este modo, el Juicio individual se transformó en la esperanza en la salvación de la humanidad, mostrando la posibilidad de un estadio, donde purgar los pecados en la visión del sacrificio de Cristo, así como en el papel intercesor de la Iglesia Triunfante. Sin embargo, en la presentación de la Magdalena, San Miguel es el protagonista de un ciclo iconográfico clásico de Psicostasis o pesaje de las almas al ser representado como psicopompo entre los justos y los condenados al Infierno, pesando en la balanza las buenas y malas acciones, las virtudes y los vicios, personificadas en pequeñas figuras que encarnan los pecados del que va a ser juzgado (Rodríguez, 2012:11-20) y (Calzada, 2007:148 y 151). Por ello, el ángel favorito de Dios, en la lucha de los cristianos contra el pecado fue representado tanto en su versión clásica de la Justicia como de soldado que se enfrenta al diablo con la espada crucífera. La pérdida del resto de la composición deja sin aclarar cuál fue el resto de su indumentaria, aunque a partir del siglo XV, la iconografía de San Miguel cambió la cota de malla medieval por una armadura metálica, la espada flameante y la cimera, no presentes en este modelo. Esta iconografía sitúa a la representación en la visión del Juicio Final anterior a 1563, donde San Miguel como psicopompo juzgará a la sociedad, señalando quien merece entrar en el Paraíso y quien debía ser enviado a los Infiernos. Con ello, el modelo de la Magdalena encuentra sus semejanzas más cercanas en el Juicio Final del primer estrato de las pinturas del lucillo de la iglesia de $\mathrm{El} \mathrm{Atance}^{10}$, su paralelo más cercano, donde se reproduce la visión tremendista y medieval de un San Miguel también anterior a Trento, aunque por su ubicación en una capilla del templo se preste a una valoración diferente (López de los Mozos, s.r:8-10), (Batalla, 1994:198-199) y (Cuevas, 2011: s.r.).

Por ende, los diablillos intervienen en la escena intentando llevar por medio de ganchos a los condenados hacia la llamas del infierno. Los demonios en su representación recuerdan que son ángeles caídos, asumiendo en su imagen características de diferentes animales y gryllas $^{11}$ (López, 2014:39-64). La pérdida del lado de los justos, obliga a centrar la interpretación en los condenados que esperan piadosos el juicio de sus almas. En ésta, la representación de la sociedad parece centrarse en aquellos que en vida habían descuidado cualquier propósito de una vida cristiana, sobre todo en un periodo, en el que la corrupción de la religiosidad había llevado al hombre a una visión laica del trance y del temor a Dios en el momento del Juicio.

Por ello, en un simbolismo que va más allá de las imágenes, se tomó la iconografía clásica, valorándose la ubicación para mostrar un Juicio Final donde todos los hombres serán juzgados. De ahí, la representación de los clérigos, del rey, de la nobleza y de las altas jerarquías de la Iglesia, en definitiva, del orden social establecido. Por eso, entre los dignos juzgará severamente al estamento eclesiástico, el más representado, al que se asocia con los vicios (la lujuria) que amenazan la vida del buen cristiano, en una clara crítica humanista a favor de la necesaria reforma espiritual del clero (López, 2006:39-52) y (Vila-Belda, 2016:21).

8 San Agustín fue uno de los primeros teóricos que abordaron la multiplicidad de los juicios de Dios. Con ello, el teólogo defendió la existencia de dos juicios, uno individual en el momento de la muerte física y otro colectivo con el Apocalipsis. Véase "De civitate Dei”, capítulo primero. Ambos aparecen diferenciados en la iconografía por la Psicostasis y el Juicio Final.

9 El Concilio de Trento, en la sesión $\mathrm{n}^{\mathrm{0}} 25$ de los días 3 y 4 de diciembre de 1563, acordó que los curas enseñaran y predicaran la existencia del Purgatorio, excluyendo de los sermones las aspectos más difíciles y sutiles.

10 En el pueblo de El Atance, al retirar uno de los retablos del siglo XVIII, se descubrieron unas pinturas con el tema del Juicio Final. El lucillo, un verdadero palimpsesto, muestra como el lóculo mantuvo vigente el tema teológico, adaptando la iconografía según las percepciones de cada época, tremendista en su primer nivel y esperanzadora en su estrato final. Las pinturas murales se conservan en el Museo de Arte Sacro Diocesano de Sigüenza. En su cronología, la representación de San Miguel en la Psicostasis se ha fechado como anterior a Trento, mientras que en su segundo nivel tendría como fecha máxima el momento de colocación de la hornacina que lo cubrió en 1703.

11 Las diferentes representaciones del demonio, de las gryllas y, de la mujer asociada a la lujuria, aportan al conjunto una impronta medieval que, sin embargo, no sugiere el pesaje de las almas, dos personajes vestidos sin sexo definido, uno implorando y otro con un libro en la mano, en lugar de la tradicional representación de Adán y Eva. 
En Castilla, los intentos de una renovación espiritual ya se habían planteado tanto en el Concilio de Aranda (1473) como en el sínodo anterior de Valladolid (1332) (Bonachía, 2010:269298). Sin embargo, a pesar de la legislación, las infracciones seguían siendo frecuentes entre los prelados del siglo XVI, criticándose especialmente el concubinato, porque éste y otros vicios considerados nefastos por la sociedad habían llevado a los eclesiásticos al desenfreno mundano y al abandono de la espiritualidad. En este deseo de reforma, también deben valorarse los intentos renovadores de Cisneros e Isabel la Católica. Su deseo de una religión interior, más auténtica, generó casi de un modo circunstancial el fenómeno popular de los "alumbrados," movimiento que contó entre sus seguidores con numerosos franciscanos ("los recogidos"), conversos y algunos miembros de la nobleza castellana que vieron en la reforma cisneriana la posibilidad de una nueva espiritualidad ("los dejados"). En su difusión por Castilla, uno de sus principales focos fue Guadalajara donde contaron con la protección del duque del Infantado, aunque la Inquisición pronto sospechó de su particular interpretación de la doctrina (Edicto de 1525), sentenciando a sus líderes en un auto ejemplar en 1529 (De la Inmaculada, 1958:49-80) y (Foley, 1983: 527-532).

Casi con seguridad, el resto del tema iconográfico se debió completar con la figura de Cristo luminoso (mandorla) sobre el arco iris acompañado de serafines que indican con su presencia el trono de Dios, así como por la clásica Triada divina (Déesis bizantina) (Ap.4,28). En este caso, en una representación poco frecuente de Cristo flanqueado por San Juan Bautista y María. Estructura compositiva que encontramos en el Políptico de Gante de los hermanos Hubert y Jan van Eyck (1432) y en el óleo sobre tabla del Juicio Final de Juan Correa de Vivar del Museo del Prado (1545), aunque su paralelo estético más cercano se encuentre en el Juicio Final del ábside del retablo mayor de la catedral vieja de Salamanca, obra realizada entre 1430 y 1450 por el italiano Nicolás Florentino.

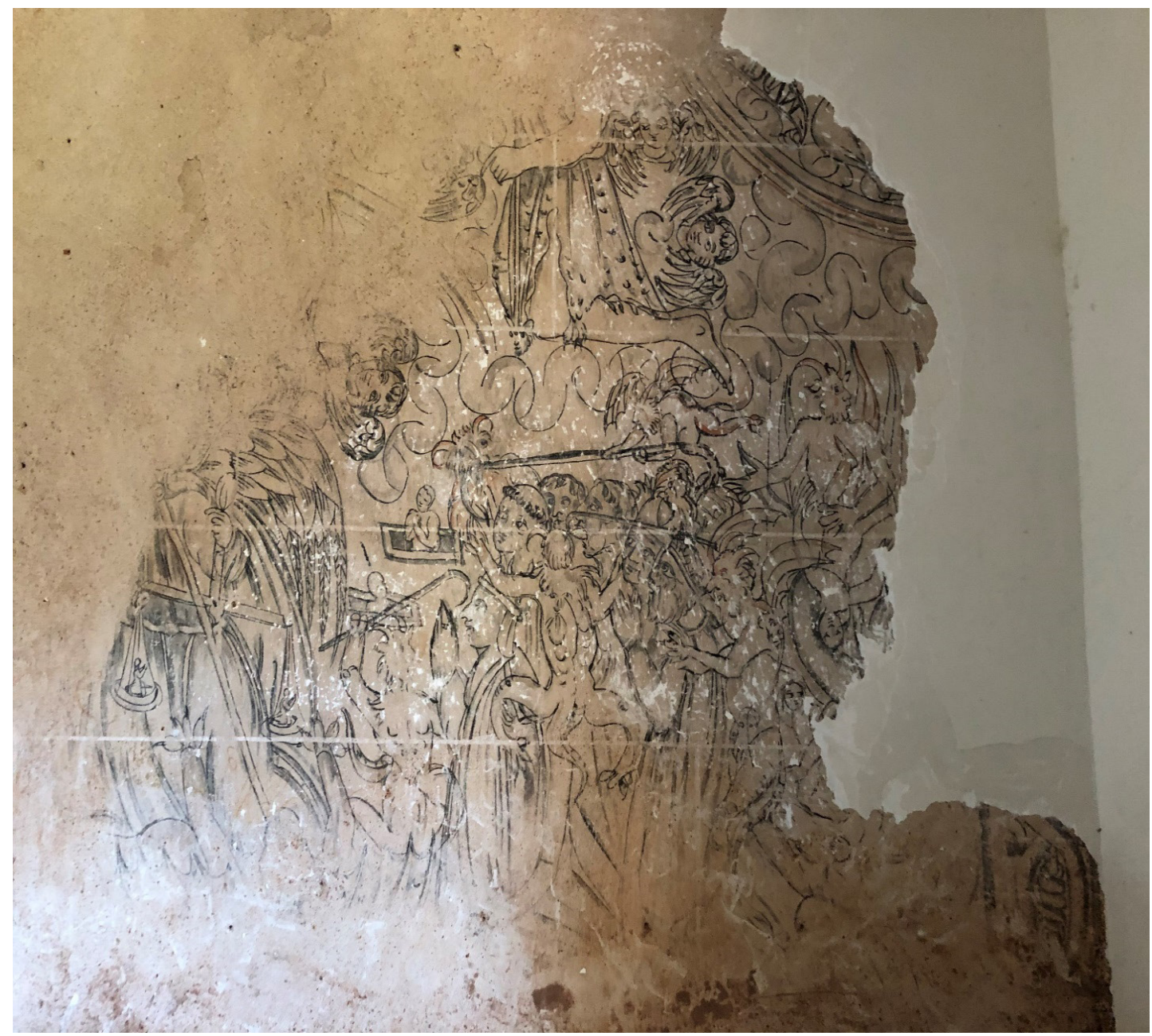

Figura. 1, Juicio Final en el Testero de la Sacristía de la Iglesia de La Magdalena. (Santamera, Guadalajara). (Fuente: Elaboración propia). 
En este contexto cultural, cabe entender la singularidad del Juicio Final de la sacristía de la Magdalena como una llamada a los clérigos que predican la palabra de Dios para que se acomoden a la humildad y al decoro que exige la vida evangélica. Interpretación que es necesario valorar en la visión que sus contemporáneos tenían del pecado, entendida casi como una falta justificada en su pertenencia a un orden social. Por ello, es interesante la visión que aporta Le Golf en base a documentos clericales de la época donde cada pecado fue asociado a un oficio o grupo social. Así, como debilidades, la simonía caracterizaría a los clérigos seculares, la hipocresía a los monjes, y la lujuria, a una buena parte del estamento eclesiástico (Le Golf, 1990:29-30). En conclusión, es posible interpretar la pintura del testero, su Juicio Final, como la propuesta de un ideólogo que intento combatir con una iconografía didáctico-moralizante el comportamiento del clero de la parroquia de la Magdalena en el siglo XVI.

\subsection{LA EMBAJADA JAPONESA DE 1614 EN SU VIAJE A ROMA. EL PODER DE LA EVANGELIZACIÓN.}

El segundo conjunto es difícil de adscribir a un repertorio temático, aunque podría corresponder a la representación de la embajada japonesa que visitó la corte de los Austrias en 1614. Escenas que podrían calificarse de excepcionales tanto por su temática como por la calidad del dibujo preparatorio, por ello es necesario que lo aquí expuesto, se tome con las reservas que una restauración del conjunto permitirá determinar con exactitud.

La primera escena para analizar es la comitiva denominada como principal por ser la que ofrece una mayor superficie descubierta. En ella, se muestra a dos personajes de rasgos orientales y vestimenta militar siguiendo a un tercero, barbado y de aspecto occidental, que se vuelve hacia ellos indicándoles el camino a seguir. El sentido narrativo de la composición es palpable en los gestos y actitudes de los personajes que marchan animosos en una disposición oeste-este. El fondo de la composición es vegetal, determinado por un paisaje abigarrado de parras y pámpanos, o de posibles hojas de loto, símbolo de la pureza física y espiritual. Entre estos motivos, dos aves enfrentadas contemplan la acción; ambos elementos iconográficos relacionados con el simbolismo de la Eucaristía y, por el tipo de ave, con Jesús. Cierra la escena en su parte inferior, una serie que repite el diseño de la flor llamada "del paraíso". En cuanto a la vid, la asociación de su simbolismo con el cristianismo es clara. Ya dijo San Juan: "Yo soy la vid, vosotros los pámpanos, el que permanece en Mí, y yo en él, este lleva mucho fruto; porque separados de Mi nada podéis hacer” (Juan 15:5), (Quiñones, 2002:702-747).

La presencia de estos elementos de naturaleza exótica debe entenderse en la espiritualidad barroca y en el deseo de incorporar a las iconografías un simbolismo visual y moderno que ensalzase los dogmas de la Iglesia. En ello, el análisis zoológico de las aves representadas ha permitido diferenciar dos ejemplares de la llamada "ave del paraíso"12 (García, 1996:131-152). El dimorfismo sexual propio de la especie fue destacado en la representación, mostrando a un macho de plumas rectrices largas y acintaladas, patas fuertes y pico curvo, de la hembra de apariencia mucho menos vistosa. En su exotismo, el ave fue interpretado por sus coetáneos como una muestra de la existencia del paraísoy, por tanto, un simbolismo viviente de la divinidad. Aunque hay una tipología amplia en la representación de esta ave, la simplificación de la misma parece responder al modelo difundido en el siglo XVII, "ave de pequeña cabeza con un cúmulo de plumas filiformes que se expanden hacia la cola"(Morgado, 2015:1-23). En España, el simbolismo religioso de esta ave, pronto se relacionó con la vida contemplativa y las virtudes del fundador de los jesuitas, aunque la presencia de los dos sexos sugiere un simbolismo más elaborado, propio de la interpretación agustiniana de "la manucodiata," que identifica a Cristo como altar sobre el que la hembra o alma nidifica, según creencia de que el ave ponía los huevos (las buenas obras, los méritos) sobre la espalda del macho. Simbolismo que se ve reforzado con la presencia de la flor "Strelitzia reginae" (ave del paraíso) en la parte baja de la escena. Este motivo denominado por el Papa Pablo V como "la flor de Cristo" fue definido como tal, en torno a 1609, al encontrarse similitudes entre los elementos de la flor y los signos de la pasión (Salvo, 2013:s.r.).

En la investigación se presentan diferentes argumentos que pueden ayudar a relacionar estas pinturas con el paso de la comitiva japonesa de 1614 por Santamera, una aldea significada en el devenir histórico por la ubicación sacro-jerárquica de su ermita a Santa Emerenciana.

12 Por su localización, el ave del paraíso es un pájaro exclusivo de las islas de Nueva Guinea. Su llegada a Europa guarda relación con la carga que trajo Sebastián Elcano en la nave Victoria en 1522. 

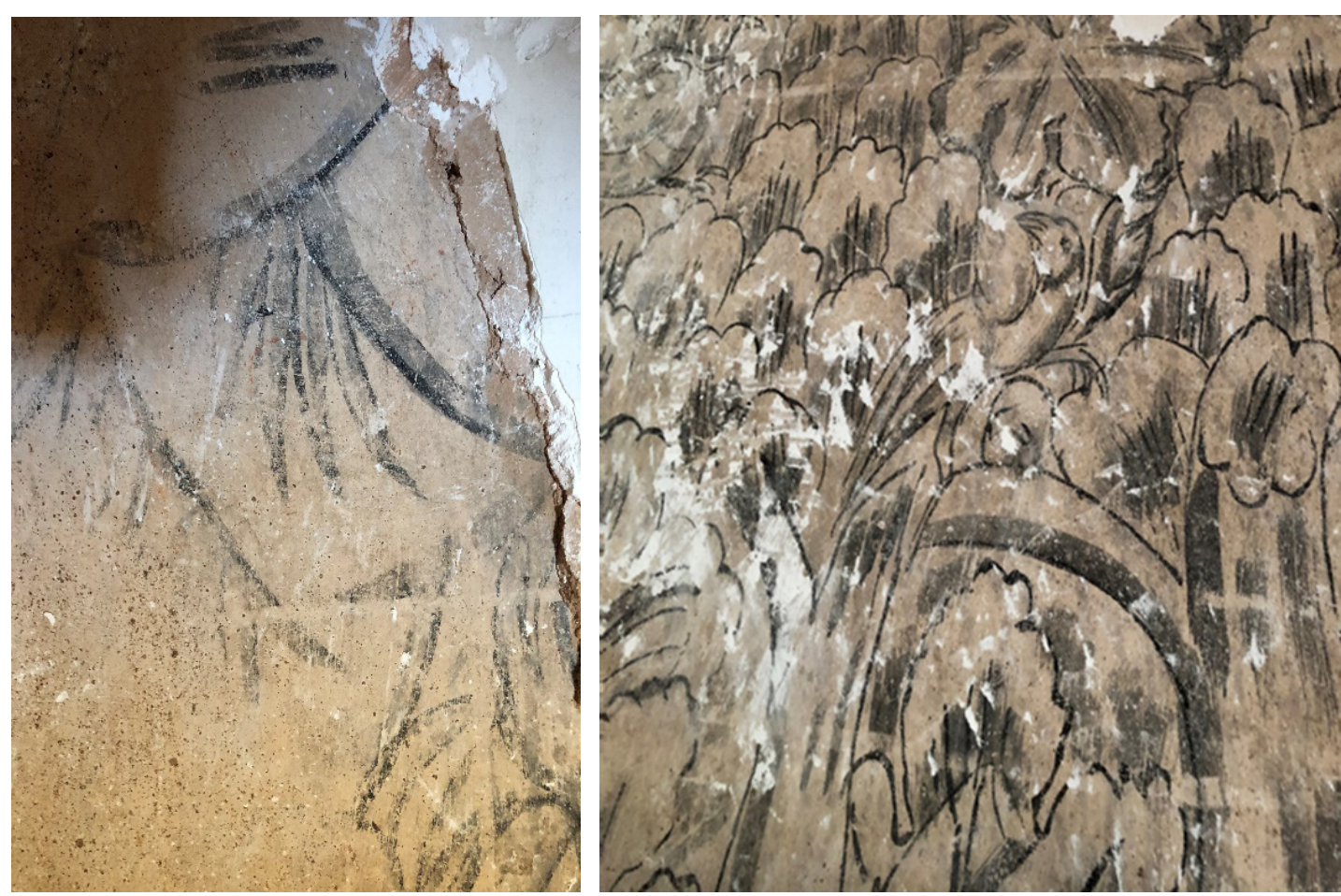

Figura 2. Detalles de la primera comitiva. De arriba a abajo, sobre el zócalo, la flor "Strelitzia Reginae" (ave del paraíso) y entre la composición vegetal, el ave del paraíso (fuente: elaboración propia).

La primera referencia es una anotación del libro de fábrica de 1601-1634 de la parroquia descubierta con anterioridad a las pinturas, anotación difícil de interpretar fuera del contexto que se propone. En este escrito, el mayordomo hace un apunte empleando el término bijeny "más ya que/ y a qué / un bijeny no por asentar de un seqito gastos de unas horas" ${ }^{13}$ que, en las referencias etimológicas ${ }^{14}$ encontradas para este término, responden a una denominación antigua empleada en el Japón del siglo XVII para referirse a las representaciones de "hombres o mujeres" en las ilustraciones Ukiyo-e, aunque también pueda encontrarse en alguna crónica castellana como sinónimo de persa u oriental. Sin embargo, en la identificación del término bijeny como sinónimo de japonés ha sido fundamental la obra de 1621 "Relación de la persecución que huvo estos años contra la Iglesia de Iapon, y los ministros della, anua y de otras informaciones autenthicas q truxo el Padre Pedro Morejón de la Compañia de Jesús, Procurador de la provincia de Japón", ${ }^{15}$ un ejemplo que muestra como el término era de uso frecuente en las obras religiosas de la época, por lo que el mayordomo de la parroquia debió usarla como una referencia conocida capaz de justificar el paso de la comitiva con el apunte realizado.

13 AHDS, Sigüenza. Archivo parroquial de Santamera. Libro de fábrica de 1601-1635. Caja nº 1 . Aunque son escasas las referencias cronológicas en los apuntes, este documento podría datarse por su posición en el libro entre 1601 y 1617, permitiendo relacionarlo con el paso de la embajada japonesa de 1614 o misión Keicho por estas tierras .

14 Bijin es un término japonés que en el diccionario japonés-español significa "persona hermosa." Como guerrero oriental, la palabra bijeny aparece en alguna publicación como "La Historia de Persia" de Luis Dubeux (Barcelona: Imprenta del Liberal Barcelonés, 1842):65 y 220

15 La obra se imprimió en Zaragoza en abril de 1617, contando con la aprobación del arzobispado y del propio rey Felipe III. Se puede consultar en: https:/books.google.es/books?id=CjZiAAAAcAAJ\&pg=PA65\&lpg=PA65\&dq=bijeny\&source=bl\&ots=mln9TogzAG\&sig=ACfU3U0WhQ4JjJaEzSIOG2PY9UVaT0AGMg\&hl=es\&sa=X\&ved=2ahUKEwiPl_Sy6oDwAhVhu3EKHXPrB_04HhDoATAJegQIBxAD\#v=onepage\&q=bijeny\&f=false 


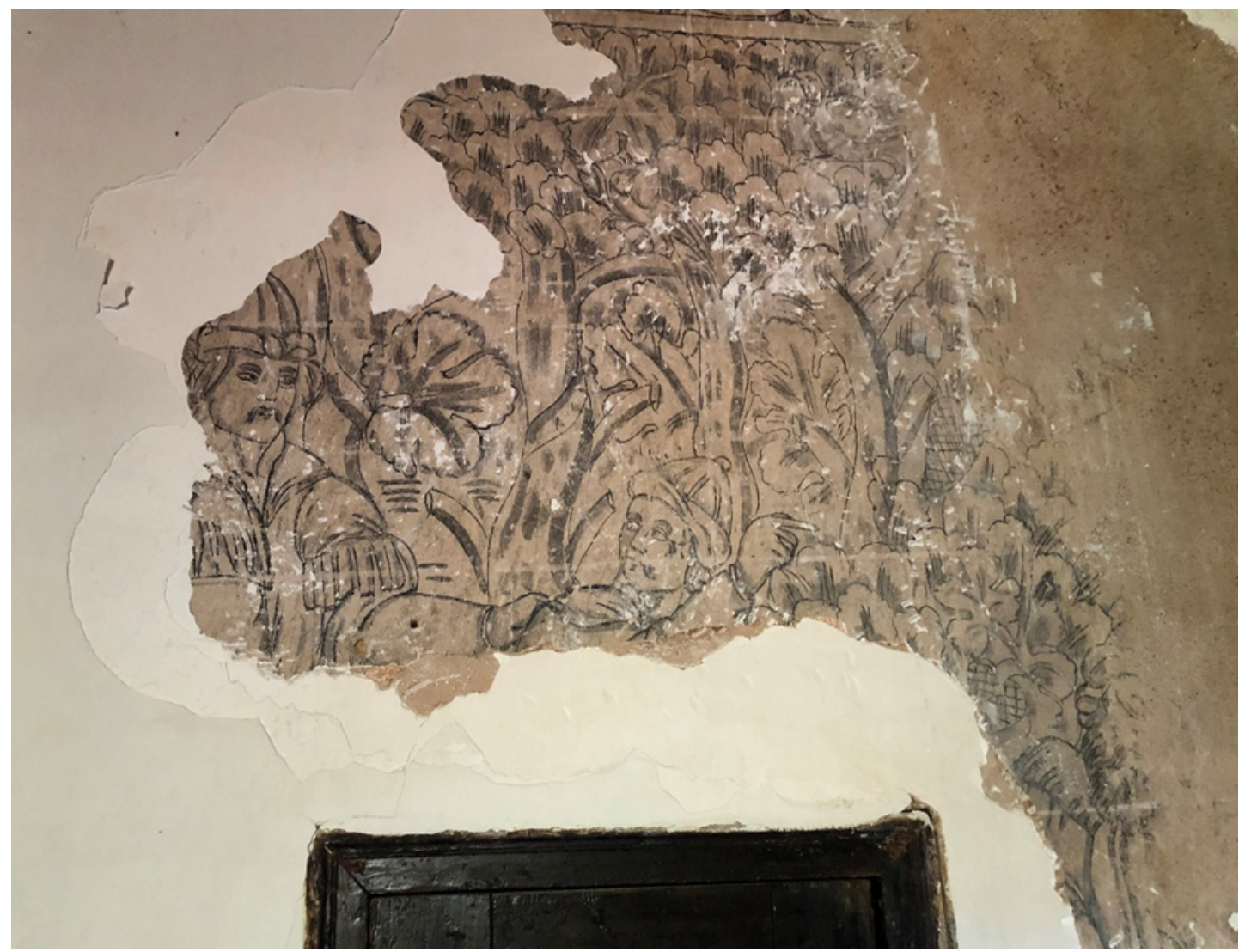

Fig. 3. Escena del muro norte de la sacristía con la representación de la embajada japonesa en un paisaje abigarrado donde predomina el simbolismo de una iconografía eucarística. Obsérvese la diferente altura entre los dos samuráis, detalle que fue destacado por la crónica papal en su recibimiento en Roma. (Fuente: elaboración propia).

El segundo, necesariamente, es la representación en la sacristía de unos personajes con rasgos físicos e indumentaria orientales asociados a una iconografía eucarística. El origen de las embajadas japonesas a Europa, muy del gusto de los Austrias, tuvieron como misión mostrar el triunfo de la fe en "los reynos de Japón," por lo que su presencia en España guardó relación con las gestiones realizadas por la Capitanía General de Filipinas para reforzar los lazos de unión entre los dos pueblos, enrarecidas en el cambio de siglo por la presencia holandesa en las costas japonesas (Shaw, 2016:79-90). La primera misión o misión Tensho (1582-1591) había sido organizada por los jesuitas durante el reinado de Felipe II con el interés de mostrar la evangelización comenzada por San Francisco Javier en 1549 y que los jóvenes católicos, hijos de los Daimyos cristianos, conocieran personalmente el mundo cristiano (Suzuki, 2018: s.r.).

La misión Keicho de 1614 tuvo un carácter más político-militar, no contando con la aprobación del Shogun, a pesar de lo cual, se realizó. Con ello, Hasekura (Fasecura) Rocuyemon, Sebastián Vizcaino y el franciscano fray Luis de Sotelo, con un séquito de 180 japoneses más, partieron para Acapulco, donde reducida la comitiva embarcaron para España (23 de julio de 1614) ${ }^{16}$ (Alvar, 1995:518-525). En ese mismo año, los enviados por Daté Masamune, señor de Woshun, llegaron a Sevilla con la intención de trasladarse a Madrid para ser recibidos por Felipe III y, después visitar al Papa, recibir su bendición y hacer entrega de unas cartas y presentes que consolidaran las relaciones entre ambas culturas. De su recibimiento desigual en Sevilla y Madrid, luego daremos cuenta, pues nos es ahora preciso destacar las referencias del viaje (Colomar y Lázaro de Escosura, 2013).

En su visita al rey, la comitiva se había enriquecido con un intérprete y secretario, Scipione Amati, autor del Libro de Voxu que recogería los detalles del itinerario y recibimiento

16 Sobre los componentes de la expedición se puede consultar en https://en.wikipedia.org/wiki/Hasekura_Tsunenaga "El Gran Barco partió de Toshima-Tsukinoura hacia los bárbaros del sur el 15 de septiembre del calendario japonés, con Hasekura Rokuemon Tsunenaga a la cabeza, y los llamados Imaizumi Sakan, Matsuki Shusaku, Nishi Kyusuke, Tanaka Taroemon, Naitō Hanjurō, Sonohoka Kyuemon, Kuranojō, Tonenaga, Kitsunai, Kyuji. Así como 40 bárbaros del sur, 10 hombres de Mukai Shōgen y también comerciantes, hasta un total

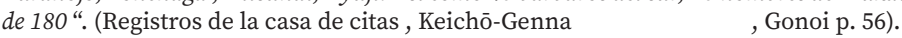


de la embajada japonesa en Roma. En el capítulo XXIII de esta obra, se destaca la ruta seguida desde Alcalá de Henares (el 22 de agosto) a Zaragoza ( 30 de septiembre) y Barcelona (3 de octubre de 1615). En esa descripción del recorrido, no se señala Santamera, ni a ninguna otra aldea del camino, pero sí se significan detalles del paso de la comitiva por los santuarios importantes. Detalles que enriquecen nuestra visión sobre cómo transcurrió el viaje, la expectación en sus recibimientos, y la devoción que mostraron los nuevos cristianos orientales en sus visitas.

En la descripción física de los orientales contamos con varias fuentes documentales que permiten ver las similitudes entre los personajes de la sacristía y los componentes de la embajada. La primera noticia es de la crónica del mejicano Chimalpahin, aunque donde se destacaron los rasgos del embajador y su séquito fue en el recibimiento de Génova (el 12 de octubre de 1615) y más tarde, en Roma (León-Portilla, 1981: 215-241), (Baliani, 1893:1-105), (Takisawa, 2009:1-29).

Era de nacionalidad japonesa y tenía entre 49 y 50 llamado Don Felipe Fasecura; el otro un español de Sevilla, por nombre Luis de Sotelo, un fraile franciscano de la Orden de la Observancia. Con ellos llevan un séquito de 28 personas, la mayor parte japoneses y todos son a excepción de uno, de baja estatura, color oliva; tienen los ojos pequeños, poca barba y se parecen mucho entre sí. Fasecura viste una larga túnica negra de terciopelo oscuro sobre la cual lleva otra corta, de seda negra, sus medias eran de seda amarilla hechas casi como sus guantes, que tiene el dedo pulgar separado del resto; y suelas de cuero, y también lleva puesto un sombrero de fieltro negro. El embajador y sus amigos tienen afeitado lo alto del cabello y en el resto más largo y recogido en la nuca como una coleta. Él porta una bella cimarra y también una espada. Los otros caballeros llevan túnicas similares, pero menos ricas. Todos ellos comieron con pequeños palillos. El padre Sotelo llevaba el hábito de la orden y actuó como intérprete. ${ }^{17}$

Es cierto que, en contra de su originalidad, tenemos como la incorporación de elementos orientales a las artes fue progresiva desde el descubrimiento de nuevas tierras, en especial, con la llegada de productos orientales a Europa. Por tanto, es posible que las escenas puedan corresponderse con la reproducción de un grabado, aunque en ello siempre las obras se mostraron cautas, asimilando paisajes o personajes de un modo anecdótico ${ }^{18}$, pues como tal, los grabados orientales no llegaron a Occidente hasta el siglo XIX (González, 2005:12). Las relaciones entre España y Japón tuvieron su origen en la llegada fortuita de un barco chino con tres portugueses a sus costas (1543), comenzando un periodo de intercambios conocido como el Siglo Ibérico (1543-1640) donde japoneses, portugueses y españoles estrecharon las relaciones comerciales ${ }^{19}$, favorecidos por la labor de los misioneros (Castro, 2012:104112). Fruto de esos contactos se desarrolló el Arte Namban, o arte japonés de influencia occidental, aunque lo más significativo para entender el valor de las pinturas de la sacristía fue la necesidad de los jesuitas de sumergirse en la cultura japonesa. En ese profundo deseo de conocer sus costumbres y sus formas culturales, los misioneros escribieron multitud de cartas, descripciones e interpretaciones de la vivencia cristiana en Japón que, en su profusa difusión, mostraron la admiración por los nuevos mártires de la fe (Barlés, 2012: 71).

Otro elemento que permite reforzar el itinerario seguido por la embajada en su paso por estas tierras es el dragón del lucillo, anteriormente comentado como iconografía del segundo paramento del Juicio Final de El Atance, fechado en un momento posterior a Trento y anterior a su ocultación en 1709. Su dibujo, una muestra de exotismo, se aleja del animal alado europeo que podemos encontrar en pinturas del momento como "La lucha de San Jorge y el dragón" de Rubens del Museo del Prado (1606-1608), o en los tipos propuestos por Rafael o Tintoretto. Con ello, si se observa la representación de la capilla de El Atance, vemos que

17 Apéndice II, n ${ }^{\circ}$ 8."Visit and compliment paid to two ambassadors of the king of Oshu in the island of japan on their arrival at Genoa on the 12th october, 1615". La traducción del documento realizado por el autor a partir del texto en inglés.

18 Podemos encontrar ejemplos de la incorporación de elementos exóticos tanto en pintores flamencos (Brueghel) como italianos (Lotto, Veronés), aunque seguramente una de las evidencias más claras sea la asimilación de sus paisajes y la asociación agua-montaña. Obras como el Crucificado del Paramento de Narbona (1373-1378), el Calvario del Misal de Saint-Magloire terminado en 1412 y la Inventio Crucis del Louvre (hacia 1480) son buenos ejemplos de cómo lo oriental se introdujo en el arte de la época.

19 Entre los productos que llegaron a las clases acomodadas están las porcelanas japonesas, las lacas chinas, los marfiles de Manila y las especias de la India. Este comercio fue especialmente importante en Nueva España y en los objetos que llegaron de Oriente a través del Galeón conocido como Nao de China o Galeón Manila. En Europa, el monopolio comercial lo tuvieron los galeones de las Compañias de Indias, imitadas en el siglo XVII por los paises europeos en sus diferentes compañias orientales en un comercio directo que evitase la intermediación de España y Portugal. 


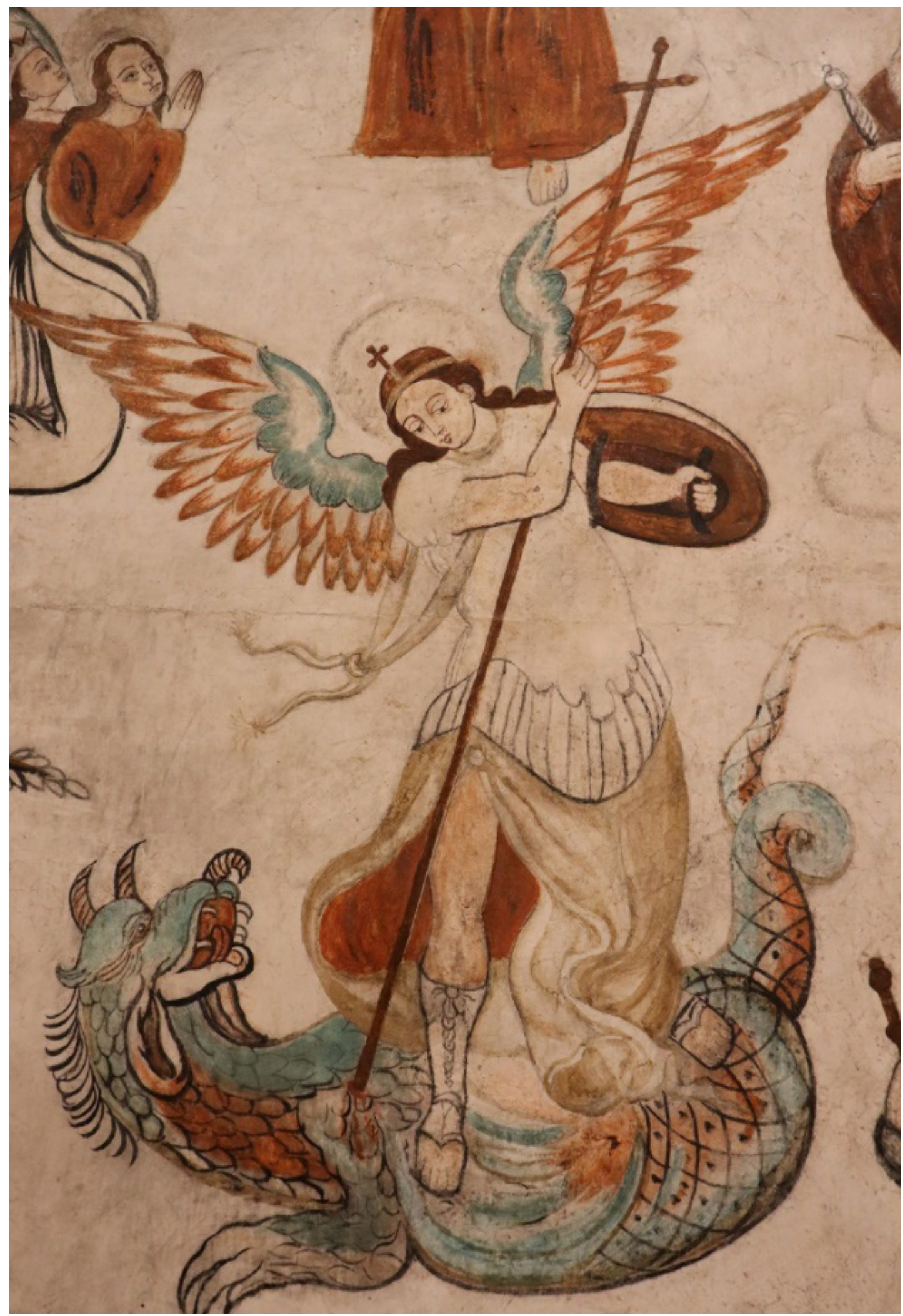

Figura 4. Dragón japonés del lucillo de la parroquia de el atance. Segundo paramento. Museo arte diocesano de Sigüenza. (Fuente : elaboración propia).

el modelo no se corresponde con la visión occidental ${ }^{20}$, sino que responde al tipo oriental de criatura serpentina de gran tamaño (Carvajal, 2012:21-28) y (Arroyo, 2012/a:105-118). Además, en una adscripción cultural, el dragón japonés muestra unos rasgos que lo significan en su

20 El dragón europeo se corresponde con un híbrido entre grifo y hombre porque se interpreta como un demonio o un monstruo feroz, en especial, a partir de 1639 con las descripciones de los místicos. En ellas, se destacan sus dientes de sierra, su piel pardo rojiza y su cornamenta de cabra. 
anatomía, presentando un cuerpo cubierto de escamas, cuernos y patas cortas con tres garras que lo distinguen del animal de cuatro o cinco garras usado como emblema imperial chino. Esta estética permite pensar que tanto exotismo en la comarca tuvo que responder a una transferencia directa de algún grabado japonés llevado allí por algún viajero, o lo que parece una evidencia más, en el paso de la embajada de 1614 por la comarca ${ }^{21}$.

Por último, una segunda escena parece mostrarnos el recibimiento ofrecido por la ciudad de Sevilla a la embajada japonesa a su llegada desde Coria. Recibimiento muy documentado que permite identificar el momento representado en la sacristía con el desfile de lo que parece un séquito y su cuerpo de guardia ante un balcón de autoridades de una gran ciudad, Sevilla. Diferentes crónicas de la época describen tanto su viaje por el Guadalquivir desde Coria como su agasajamiento en un gran acto el 27 de octubre de 1614, evento al que asistieron los hombres más importantes de la ciudad, el conde de Salvatierra en nombre del rey y el Cabildo sevillano. Las mismas descripciones narran de asombrosa la marcha de este grupo formado por el franciscano Luis de Sotelo, el embajador Hasekura Rocuyemon y su guardia de samuráis vestidos con sus uniformes de gala y sus características katanas (Colomar y Lázaro de Escosura (2013).

Destacaremos un fragmento donde se señalan las características del cuerpo de guardia que acompañó al embajador Hasekura Rocuyemon en su desfile ante la puerta de Triana.. ${ }^{22}$

Miércoles 23 de octubre de 1614 años entró en Sevilla el embaxador Japon Faxera Recuremon, embiado de Joate Masamune, rey de Boju. Traía treinta hombres japones con cuchillas, con su capitán de la guardia, $y$ doce flecheros y alabarderos con lanças pintadas $y$ sus cuchillas de abara. El capitán era christiano y se llamaba don Thomas, y era hijo de un mártyr Japón. Venía a dar la obediencia a Su Santidad por su rey y reyno, que se avía baptizado. Todos traían rosarios al cuello; y él venía a recibir el baptismo de mano de Su Santidad. Venía en su compañia fray Luis Sotelo, natural de Sevilla, religioso de San Francisco recoleto. Salieron a Coria a recebirlo por la Ciudad, el veinticuatro don Bartolomé Lopez de Mesa, y el veinticuatro don Pedro Galindo; y junto a la puente los recibió la Ciudad. Entró por la puerta de Triana, y fue al Alcázar, donde la Ciudad lo hospedó, y hizo la costa mientras estuvo en Sevilla.

La lectura de estos documentos permite identificar al jinete o samurái conservado en la sacristía con los soldados del séquito, pudiéndose establecer una correlación por la indumentaria que caracterizó a estos guerreros orientales. En principio, lo más significativo es su casco, una especie de morrión modificado (kabuto y menpo) y su chaqueta corta de cota de malla (kusari katabira), vestimenta que permitía la protección con el uso de la ropa ordinaria y que fue muy popular en el periodo Edo. Además, se puede apreciar el uwa-obi (himo), faja de tela que servía para unir armas como la katana, el wakizashi y el tanto, un sable de filo único y curvo de alrededor de un metro. También, porta el samurái un yari (lanza) del que cuelga una pequeña banderola (sashimono) con la muy probable heráldica de su señor ${ }^{23}$. Representación que aproxima a este guerrero con la guardia que tuvo a su cargo la seguridad de los nobles japoneses en su venida a Europa (Wayne, 2018) y (Absolon y Thatcher, 2011:57). Por otra parte, el conjunto arquitectónico de la ciudad representada permite establecer un cierto paralelismo con la imagen de la ciudad de Sevilla aportada por los textos y grabados ${ }^{24}$ de la época.

Finalmente, la expedición japonesa marchó a Madrid donde el Consejo de Indias había recomendado un recibimiento oficial frío y distante (20 de diciembre de 1614) que determinó

21 La comitiva en su trayecto a Zaragoza debió elegir la ruta del Henares al valle del Salado, pues se señala Daroca y no Sigüenza, y pensamos que habría sido una referencia obligada de haber transcurrido por allí el viaje. El exotismo del dragón del El Atance no hace más que reafirmar nuestro planteamiento.

22 La entrada en Sevilla también fue relatada a posteriori en el libro de Voxu de Scipione Amati. El texto que mostramos es de la Biblioteca Capitular Colombina 84-7-19. Memorias..., fol.195. http://www.icolombina.es/archivo/index.htm // https://es.wikipedia. org/wiki/Hasekura_Tsunenaga

23 El escudo de armas de Hasekura Rokuemon era una esvástica budista cruzada por dos con una corona sobre fondo naranja

24 Entre éstos, el grabado de Petrus Tortolero muestra la entrada de Felipe V por la puerta de Triana a la ciudad (1729). Obsérvese las coincidencias tanto en las torres de las iglesias como en los detalles de las banderolas. Disponible en: https://es.wikipedia.org/ wiki/Archivo:Entrada_de_Felipe_V_en_Sevilla_en_1729._Pedro_Tortolero.jpg 
su partida para Barcelona (10 de marzo de 1615), llegando a Génova el 12 de octubre de 1615. Cumplida su misión en Roma, la misión Keicho, tras dos años en Europa (julio de 1617) intentó regresar a un país que ya no era el mismo, pues la política aislacionista japonesa había promulgado un edicto en enero de 1614 ordenando la expulsión de todos los misioneros del país, por lo que los acuerdos con España fracasaron y, con ello, las islas se cerraron a la cultura occidental y al cristianismo.

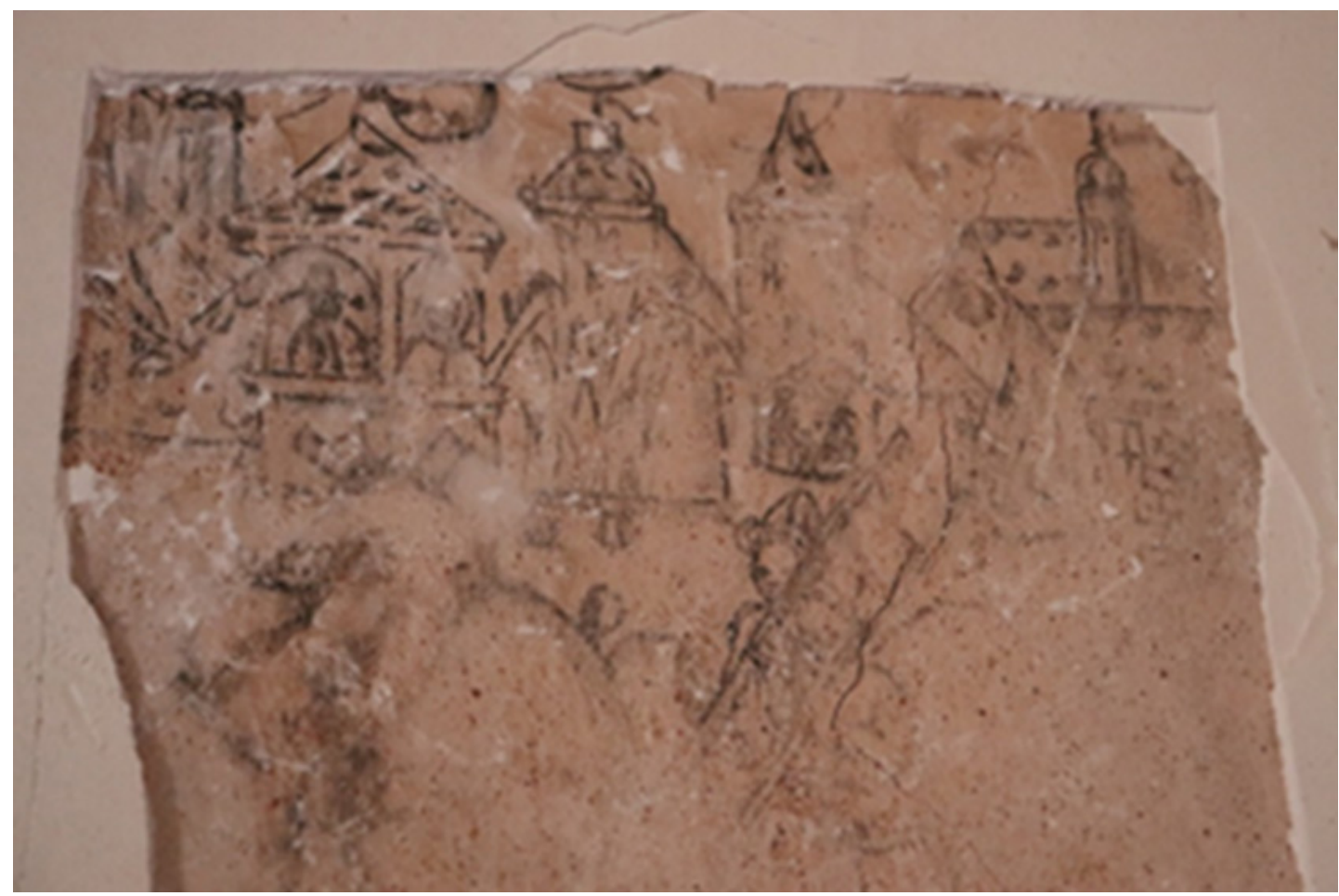

Figura 5. Fragmento de la pintura aparecida en el muro oeste. Paso del séquito y palco de autoridades en la puerta de Triana. (Fuente: elaboración propia).

\section{CONCLUSIONES}

A pesar de la posible identificación de la comitiva desconocemos las razones que llevaron a la representación de esta singular embajada en la sacristía, aunque si valoramos la iconografía eucarística, aceptamos el paso del exótico grupo de cristianos por el valle y contextualizamos la obra en un periodo de divulgación de la labor misionera en Oriente, el conjunto cobra sentido al mostrar el triunfo de la fe de la Contrarreforma sobre la herejía. Con ello, es importante valorar la temática en el contexto generado por la división religiosa entre católicos y protestantes en el siglo XVI, polémica que favoreció la proclamación de nuevos mártires, sobre todo cuando el descubrimiento de las catacumbas generó un auténtico debate sobre quiénes eran los verdaderos sucesores en la fe de los cristianos. En ese sentido, la evangelización de Japón, con sus persecuciones y martirios, ofreció una imagen contemporánea de santidad, un modelo a seguir que generó la publicación de un buen número de obras donde se ensalzaron tanto la labor de los misioneros como las fuertes convicciones de los nuevos cristianos. Sirva como epílogo para entender la importancia del tema en la época, el relato aportado por Lope de

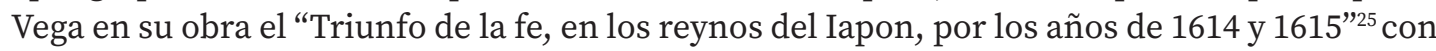

25 (Madrid,1618), 7. En 1617, el escritor había recibido una carta del dominico Jacinto Orfanel en la que le contaba como habían sucedido los últimos martirios de 1614; su intención que el afamado autor divulgara el trabajo de los misioneros para ganar mayor protección de España y Roma. Entre la numerosa bibliografía del periodo destacar las obras del misionero franciscano Marcelo Ribadeneyra (1601), de Luis Piñeiro (1617 y de Diego de San Francisco (1625). La obra de este último recoge las actas de la audiencia pública del papa Pablo V a la embajada de Hasekura Tsunenaga (capítulo VLT), entregadas personalmente por Fray Luis Sotelo al autor, antes de su martirio (capítulo XX). La obra de Lope de Vega en su edición original se puede consultar en: http:// www.memoriademadrid.es/buscador.php?accion=VerFicha\&id=56660\&num_id=19\&num_total=58 [Consultada el 28-04-2021]. El libro de Diego de San Francisco disponible en : https://bibliotecadigital.rah.es/es/consulta/registro.do?control=RAH20100002339 [Consultada el 29-04-2021]. 
la noticia de las embajada japonesa a Roma y al rey católico, así como en la fortaleza de los nuevos mártires a los que el escritor compara con los primeros santos de las persecuciones romanas y de tierra de moros.

Además, en cuanto a simbiosis artística del arte japonés con el occidental, las pinturas de la sacristía parecen responder por su carácter narrativo al concepto de un tipo de Namban Byobu $^{26 .}$ Estos biombos representaron escenas de temática occidental como la llegada de los barcos portugueses a las costa de Japón, su desembarco y su procesión hasta la iglesia católica. De igual modo, en una posible reinterpretación de la temática de los Namban Byobu, se mostraría la despedida de la comitiva en Sevilla (asimilada como el inicio del viaje en el puerto de Goa), su trayecto (las comitivas) y la llegada a la iglesia, en este caso con el recibimiento del papa en Roma, final de un itinerario que podría corresponderse con una pintura del siglo XVII, conservada en Japón. (Fig.6) (García, 1989:61-65).

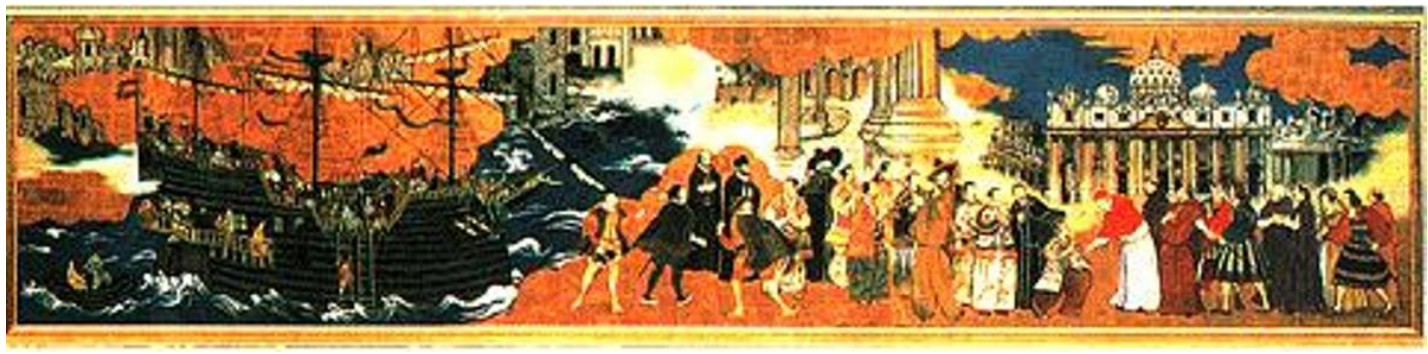

Figura 6. Llegada de la embajada de Hasekura a Roma en 1615 . Pintura japonesa del siglo XVII. Imagen tomada de archivo de dominio público: San Juan Batista.jpg. https: //en.wikipedia.org/wiki/luis sotelo

\section{BIBLIOGRAFÍA}

- Alvar, M. (1995). La embajada japonesa de 1614 al rey de España. THESAURUS. Tomo L, 1, 2 y $3,518-525$.

- Arroyo Cuadra, S. (2012/a). La iconografía del dragón y del grifo: mismo origen, distinto destino. Eikon / Imago 1, 105-118.

- Amati, Scipione (1615). Historia del Regno di Voxu del Giapone dellántichita, nobilta, e valore del suo re Idate Masamune delli favor, c'ha fatti...Dedicata allá Sta. Dei N.S. Papa Paolo V fatto por il Dottor SciiponeAmati romano, interprtete, historico dell'Ambasciata, in Roma, Apreffo Giacomo Mafcardi, MDCXV.

- Baliani G. B. (1893). Colyer Meriwether. 1615: l'ambasceria di Date Masamune a Genova. La nuova scienza. Disponible en: http://uranialigustica.altervista.org/baliani/secondarie/meriwether.htm.

- Documentos consultados de la obra original de Colyer Meriwether. Transactions of the Asiatic Society of Japan 21 (1893), pp. 1-105.

- Apéndices II. $\mathrm{n}^{\circ}$ 8. Visit and compliment paid to two ambassadors of the king of Oshu in the island of japan on their arrival at Genoa on the 12th october, 1615.

- Barlés Baguena, E. (2012). La investigación del arte japonés en España En P. Cabañas Moreno y A. Trujillo Dennis (coord.). La creación artística como puente entre Oriente y Occidente Sobre la investigación del Arte Asiático en países de habla hispana (pp.70-105). Grupo de Investigación Complutense Arte de Asia, Grupo de Investigación ASIA.

- Batalla Carchenilla, C. (1994). Datos de poblamiento en el curso medio del río Salado. IV Encuentro de historiadores del Valle del Henares , 39-45.

- Bonachía Hernando, J. A. (2010). La Iglesia de Castilla, La reforma del clero y el Concilio de Aranda de 1473. Biblioteca: estudio e investigación 25, 269-298.

- Borja Gómez, J. H. (2009). Purgatorios y Juicios finales: las devociones y la mística del corazón en el Reino de Nueva Granada, Historia Crítica 39,1, 80-100.

- Cantera Burgos, F. y Carrete Parrondo. C. (1973b). Las juderías medievales en la provincia

26 La técnica, la claridad compositiva, los primeros planos y la falta de perspectiva permiten relacionarlo con los pintores de la escuela de Kano. Artistas que estuvieron familiarizados con la vida en las misiones donde aprendieron el arte occidental. Características de un estilo que se pueden apreciar en las escenas de la sacristía de la Magdalena. 
de Guadalajara. Continuación. Sefarad 33(2), 260-323.

- Calzada Toledano, J.J. (2007). El Juicio Final de San Nicolás. Boletin de la Institución Fernán González 86, 234, 151.

- Carrete Parrondo, C., y Moreno Koch, Y. (1995). ¿Ecclesia versus iudaeos? Clérigos judaizantes del obispado de Sigüenza. Helmática: Revista de filología clásica y hebrea 46 (139-141), 283-292.

- Carvajal González, H. (2012). San Jorge. Revista Digital de Iconografía Medieval, IV,7, 21-28. Disponible en: https://www.ucm.es/bdiconografiamedieval/san-jorge [Consultada el 14-04-2021]

- Castro Caridad, E.M. (2007). El Juicio Final en textos litúrgicos medievales”, Vegueta 17, Anuario de la Facultad de Geografía e Historia, 39-61.

- Castro Rodríguez, F. (2012). La influencia asiática con especial énfasis en Japón, y su impacto en las artes de la Nueva España. En P. Cabañas Moreno y A. Trujillo Dennis (coord.). La creación artística como puente entre Oriente y Occidente Sobre la investigación del Arte Asiático en paises de habla hispana (pp.105-112). Grupo de Investigación Complétense Arte de Asia, Grupo de Investigación ASIA.

- Colomar Albajar, M. A. y Lázaro de Escosura, P. (2013). De Japón a Roma buscando el sol de la cristiandad. La embajada de Hasekura (1613-1620). Catálogo, Sevilla: Ministerio de Educación, Cultura y Deporte.

- Documentos consultados:

- - Carta del Embajador Hasekura al rey de España. 1614, septiembre. Archivo General de Simancas. Estado, 256-1,126.

- - Carta del Embajador Hasekura al duque de Lerma. 1614, septiembre. Archivo General de Simancas. Estado, 256-1,127.

- - Carta de fray Luis Sotelo al rey. 1614, octubre. Archivo General de Simancas. Estado, 255,230

- - Memoria de la ropa que se da al embajador del Japón, y lo que monta mensualmente. Archivo General de Indias. Filipinas, $37, \mathrm{n}^{\circ} 13$.

- Cuevas, Oscar.(2011). Salen a la luz las pinturas de la iglesia del Atance. ABC Castilla LaMancha, 4 de Abril de 2011.

- De la Inmaculada, Román (1958). El fenómeno de los alumbrados y su interpretación. Ephemerides Carmeliticae, 49-80.

- Foley, A. E. (1983). El alumbradismo y sus posibles orígenes. En Actas del VIII Congreso de la Asociación Internacional de Hispanistas, vol. 1(Providence: Brown University,1983), 527-532.

- García Arranz, J.L. (1996). Paradisea avis la imagen de la naturaleza exótica al servicio de la enseñanza didáctico-religiosa en la Edad Moderna. Norba: Revista de arte 16, 131-152.

- García Gutiérrez, F.(1967). Características del arte de Japón. Boletín de la Asociación Española de Orientalistas, Año 3, 17-21.

- - -(1989). Los Namban Byobu de Japón (unas pinturas con temas occidentales), Laboratorio de Arte 2, 61-65.

- Gismera Velasco, T. (2016). Historia de las Salinas de Atienza. Guadalajara: Tomás Gismera Velasco.

- González Linaje, M.T.(2005). La pintura del paisaje: del taoísmo chino al romanticismo europeo: paralelismos plásticos y estéticos. Universidad Complutense de Madrid. Disponible en: https://eprints.ucm.es/id/eprint/5488/1/T27142.pdf [Consultada el 14-03-2021]

- Marco Martínez, J. A (1997). El retablo barroco en el antiguo Obispado de Sigüenza. Guadalajara: Diputación Provincial de Guadalajara, 1997.

- Morgado García, A. (2015). De la visión emblemática a la visión desencantada: los animales en el mundo hispánico (siglos XVII y XVII), Bulletin of Spanish Studies ,1-23.

- Layna Serrano, F. (1944). Los estilos Renacimiento y Barroco en la provincia de Guadalajara. Archivo Español XV, 9.

- Le Goff, J. et al.(1990). El hombre medieval. Alianza. Madrid.

- León- Portilla, M. (1981).La embajada de los japoneses en México, 1614.Estudios de Asia y África, XVI, (2) , 215-241. Disponible en: https://studylib.es/doc/7191305/la-embajada-de-losjaponeses-en-mexico--1614.-el-testimon.

- López de los Mozos, J. R. Notas para el conocimiento de un pueblo desaparecido. El Atance, 
Guadalajara (Guadalajara: Caja de Guadalajara, s.f.), 8-10.

- López Torrijos, R. (2006). La iconografía de la Justicia en la época de Velázquez. En Actas Tras el centenario de Felipe IV : Jornadas de Iconografía y Coleccionismo : dedicadas al profesor Alfonso E. Pérez, ed. José Manuel Pita Andrade, Ángel Rodríguez Rebollo, 39-52.

- López Vázquez, J. M. (2014). Hablemos de ángeles calvos, demonios pelones y figuras grotescas en la escultura barroca gallega, Imago 6, 39-64.

- Quiñones Costa, A. M. (2002). La decoración vegetal en el Arte Español de la Alta Edad Media: su simbolismo. Universidad Complutense de Madrid. Disponible en: https:// dokumen.pub/la-decoracion-vegetal-en-el-arte-espaol-de-la-alta-edad-media.html[Consultada el 26-03-2021]

- Ramos Gómez, F. J. (2003). La pintura del siglo XVI en el obispado de Sigüenza. Anales Seguntinos 19, 35-59.

- -. Juan Soreda y la pintura del Renacimiento en Sigüenza. Guadalajara: Diputación de Guadalajara, 2004.

- Rodríguez Peinado, L. (2012). La Psicostasis. Revista Digital de Iconografía Medieval, IV,7, 11-20.Disponible en: http://webs.ucm.es/centros/cont/descargas/documento39814.pdf [Consultada el 18-04-2021]

- Salvo Tierra, E. Historia de "La flor de Cristo. La Opinión de Málaga (31-10-2013). Disponible en: https://www.laopiniondemalaga.es/semana-santa/2013/03/31/florcristiandad/577707.html [Consultada el 18-04-2021]

- Shaw, C. M. (2016). España y Japón en el siglo XVII: las dos embajadas de la era Keicho (1596-1615).Tempus 4: Revista en Historia General, 72-90.

- Suzuki, Y. (2018). Misión Tensho, la primera embajada japonesa al Imperio español de Felipe II. Revista de Historia Digital, 20-03-2018. Disponible en: https://revistadehistoria.es/ mision-tensho-la-primera-embajada-japonesa-al-imperio-espanol-de-felipe-ii/ [Consultada el 1804-2021]

- Takisawa, O. (2009). La delegación diplomática enviada a Japón por el señor feudal japonés Date Masamune (1613-1620). Archivo de la Frontera. Disponible en: https://www.yumpu. $\mathrm{com} / \mathrm{es} /$ document/read/14829517/la-delegacion-diplomatica-enviada-a-roma-por-el-senor-feundal[Consultada el 6-01-2021]

- Trevor Absolon, T y David Thatcher, D. (2011). Samurai Armaour. The Watanabe Art Museum Samurai Armour Collection, vol. I-Kabuto- Mengu. (Canada, Watabe Art Museum, Tottori, Japan). Impreso en Canada by Digital Direct Printing Ltd., Victoria.

- Vila-Belda Martí, F. (2016).Imagen y palabra. Los pecados más frecuentes en la iconografía de Castilla medieval. (Siglos XI al XV). Universidad Autónoma de Madrid. Disponible en: https://repositorio.uam.es/bitstream/handle/10486/675435/vila_belda_marti_faustina. pdf?sequence $=1$ \&isAllowed $=y$ [Consultada el 16-04-2021]

- Wayne Farris, W. (1998). Sacred Texs and Buried Treasures. Issues in the historical Archaeology of Ancient Japan. University of Hawai'i Press. 